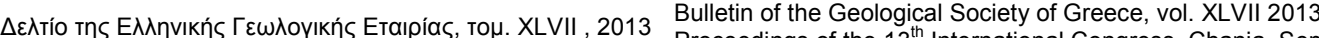
Proceedings of the $13^{\text {th }}$ International Congress, Chania, Sept.

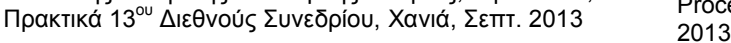

\title{
THERMAL BEHAVIOUR OF STEVENSITE AT TEMPERATURES UP TO $800^{\circ} \mathrm{C}$
}

\author{
Christidis G.E ${ }^{1}$ and Koutsopoulou E. ${ }^{2}$ \\ ${ }^{I}$ Technical University of Crete, Department Mineral Resources Engineering, 73100 Chania, \\ Greece.christid@mred.tuc.gr \\ ${ }^{2}$ University of Patras, Department Geology, 26500 Patras, Greece ekoutsop@upatras.gr
}

\begin{abstract}
Stevensite is a Mg-trioctahedral smectite with layer charge stemming from vacancies in the octahedral sheet. In the present work we studied the thermal behavior of Jbel Ghassoul stevensite from Morocco, known as Ghassoulite or Rhassoulite, free of talc layers. The clay fraction of the material was separated by sedimentation, it was subsequently heated from $250^{\circ}$ to $800^{\circ} \mathrm{C}$ and the end products were examined with X-ray diffraction (XRD) and Fourier Transform Infrared (FTIR) spectroscopy. The influence of heating on the stevensite structure begins at $400^{\circ} \mathrm{C}$ and is completed at $500^{\circ} \mathrm{C}$. It involves irreversible collapse of the layers at $\sim 10 \AA$, which do not re-expand in ethylene glycol (EG) vapors. In contrast, heating at lower temperatures does not affect the stevensite layers, which expand completely in EG. The FTIR spectra indicate the formation of talc-like (kerolite) layers after heating at temperatures exceeding $400^{\circ} \mathrm{C}$. Within the current experimental setup, the transition to kerolite layers takes place without the formation of an intermediate mixed-layer stevensite/talc phase. Heating at higher temperatures does not change the transformation pattern, until $800^{\circ} \mathrm{C}$ where complete dehydroxylation of the $2: 1$ layer takes place, which is associated with the formation of enstatite. The results of this study clearly demonstrate that opposite to common trioctahedral and dioctahedral smectites, stevensite converts to another layer silicate prior to dehydroxylation.
\end{abstract}

Key words: trioctahedral smectite, kerolite, XRD, Thermal treatment, transformation.

\section{Пєрі́ $\eta \psi \eta$}

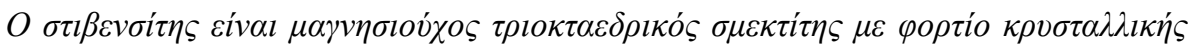

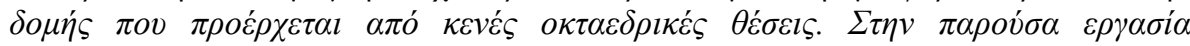

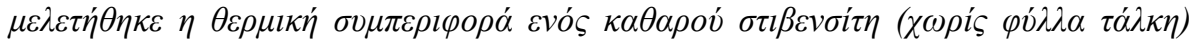

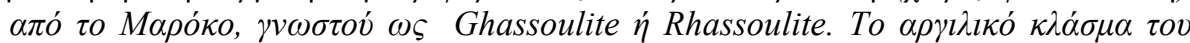

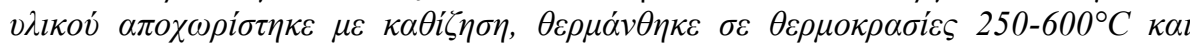

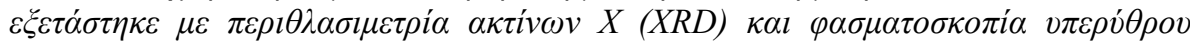

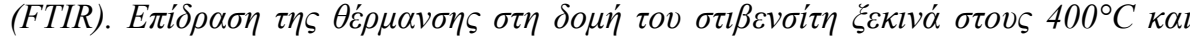

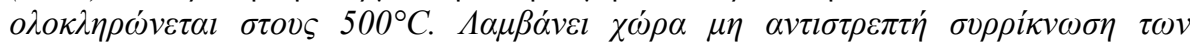

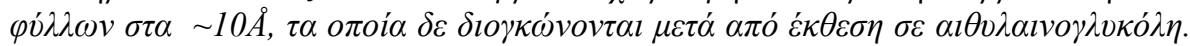

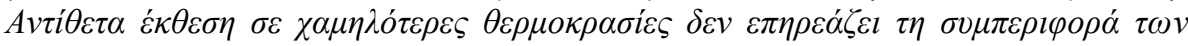

XLVII. No $1-366$ 


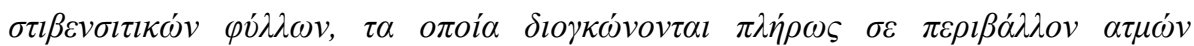

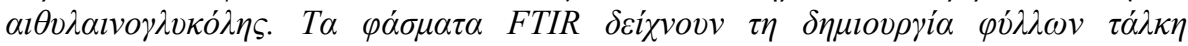

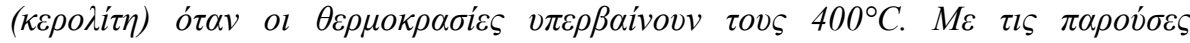

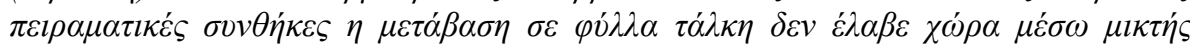

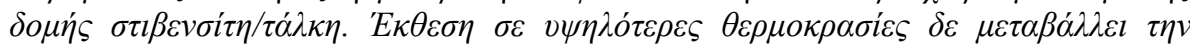

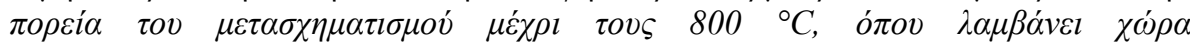

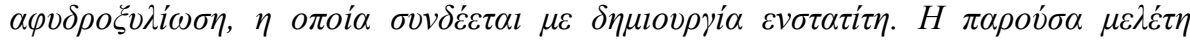

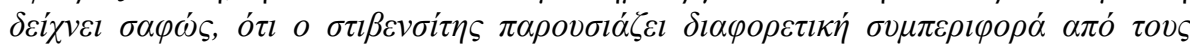

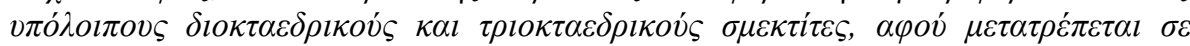

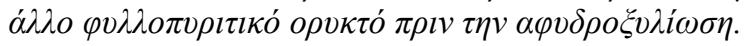

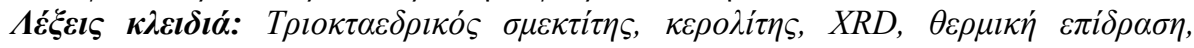
$\mu \varepsilon \tau \alpha \tau \rho о \pi \eta \dot{~}$

\section{Introduction}

The structural and crystal chemical characteristics of smectites have been studied extensively in the past by several independent analytical methods including X-ray diffraction (XRD), various spectroscopic methods including FTIR, Mössbauer and EPR spectroscopy, thermal analysis, chemical analysis (e.g. Lagaly \& Weiss 1975; Talibudeen \& Goulding 1983; Lim \& Jackson 1986; Decarreau et al., 1987; Goodman et al., 1988; Iwasaki \& Watanabe 1988; Lagaly 1994; Christidis \& Dunham 1993; 1997; Christidis \& Eberl, 2003; Christidis, 2006). Identification of smectite compositional characteristics is important for most industrial applications (Christidis, 2011). Hence several classification schemes of smectites have been proposed, based on their crystal chemical and thermal properties (Grim \& Kulbicki, 1961; Schultz; 1969; Brigatti \& Poppi, 1981; Newman \& Brown, 1987; Alberti \& Brigatti; 1985; Güven, 1988; Drits et al., 1998; Wolters et al., 2009).

X-ray diffraction (XRD) and Fourier Transform Infrared (FTIR) Spectroscopy are powerful techniques used for the characterization of structural characteristics of smectites. Special tests have been proposed for fast distinction of the different smectite species such as the Hoffman-Klemmen effect, which provides a fast tool for distinction of beidellite from montmorillonite (Greene-Kelly, 1953). However, most previous work on the identification and characterization of smectites focus on the dioctahedral smectites. In contrast, characterization of the trioctahedral smectites by XRD methods is very basic and includes merely identification of the trioctahedral character, based on the position of the 060 diffraction maximum (e.g. Moore and Reynolds, 1997).

The main trioctahedral smectite species are saponite with predominantly tetrahedral charge and stevensite and hectorite mainly with octahedral charge. Stevensite is different from its counterparts because the layer charge stems from octahedral vacancies rather than substitutions in the structure (Brindley, 1984). The layer charge of stevensites is low and typically does not exceed 0.25 electrons per half unit cell (e/huc). Studies on the stevensite thermal properties are rather rare (Shimoda, 1971; Brindley, et al. 1977; Benhammou et al., 2009). Moreover, in several occurrences, stevensite occurs in the form of mixed layer stevensite/kerolite (e.g. Eberl, et al. 1982; Dekov et al. 2008). In contrast pure stevensites are rather rare. Recently Christidis \& Mitsis (2006) described a new Ni-stevensite in Othrys mountain, Central Greece. The aim of this study was to describe the thermal characteristics of the Jbel Ghassoul stevensite from Morocco, and to display possible differences compared to the remaining trioctahedral smectites and a well characterized talc from Egypt. The particular stevensite was selected, because it is well characterized and it is well known that it does not contain traceable kerolite layers (Benhammou et al., 2009) 


\section{Materials and Methods}

The stevensite sample from Jbel Ghassoul was supplied by Prof. K. El Ass, University of Rabat, Morocco. It is a gray-pink soft clay with a low grit content and soapy texture. The Egyptian talc was provided by IONIAN KALK SA (Kefalonia, Greece). Bulk mineralogy was determined by Xray diffraction (XRD) with a Bruker D8 Advance XRD, equipped with a Lynx Eye strip silicon detector, using $\mathrm{Ni}$ filtered $\mathrm{CuK} \alpha$ radiation $(35 \mathrm{kV}, 35 \mathrm{~mA}), 0.298^{\circ}$ divergence and antiscatter slits, and a step size of $0.019^{\circ} 2 \theta$, with 47.7 s count time per step. XRD analysis was performed from 4 to $70^{\circ} 2 \theta$. The collected data were evaluated with the EVA® software provided by SOCABIM. $3 \mathrm{~g}$ of the bulk sample were heated at $800^{\circ} \mathrm{C}$ for $2 \mathrm{~h}$ and examined with the same diffractometer. Clay mineralogy was determined by dispersion of the sample in distilled water using an ultrasonic probe (20 seconds) and repeated washing until practically free of salts (electric conductivity $<25$ $\mu \mathrm{S} / \mathrm{cm})$. The $<2 \mu \mathrm{m}$ fraction was separated by settling and dried on glass slides at room temperature. The glass slides with the calibration samples were heated at 250, 300, 400, 500, 550 and $600{ }^{\circ} \mathrm{C}$ for $90 \mathrm{~min}$ and were subsequently solvated with ethylene-glycol (EG) vapour at $60{ }^{\circ} \mathrm{C}$ overnight (min. $16 \mathrm{~h}$ ) to ensure maximum saturation. XRD analysis was performed from 2 to $35^{\circ} 2 \theta$ with the same diffractometer.

The clay fractions of the stevensite in the raw state and after heating at $500^{\circ} \mathrm{C}$ were examined with infrared (IR) spectroscopy using a Perkin Elmer 1000 Fourier Transform Infrared (FTIR) spectrometer in the range $400-4000 \mathrm{~cm}^{-1}$. Each spectrum was the average of 50 scans collected at 4 $\mathrm{cm}^{-1}$ resolution. $1.5 \mathrm{mg}$ of the clay fractions was diluted in $200 \mathrm{mg} \mathrm{KBr}$ and pressed in $13 \mathrm{~mm} \mathrm{KBr}$ disks, which were subsequently dried at $150^{\circ} \mathrm{C}$ for 15 hours, prior to FTIR analysis (Russell 1987).

\section{Results}

\subsection{X-Ray Diffraction}

The XRD trace of the bulk stevensite sample is shown in (Fig. 1a). The material consists of stevensite, with minor illite, chlorite, quartz, dolomite, K-feldspar and albite. The hump at 10-18 ${ }^{\circ}$ $2 \theta$ is due to instrumental artifact. The stevensite content exceeds $90 \%$. The clay fraction contains $>95 \%$ stevensite and traces of chlorite illite and quartz (Fig. 1b). The existence of a low angle shoulder in the 001 diffraction maximum of the EG solvated XRD trace might be indicative of random interstatification, possibly with kerolite layers. However the higher order diffraction maxima are rational suggesting that if kerolite layers are present, they should not exceed 5\%. Therefore the smectite is considered to be pure stevensite. After heating at $800^{\circ} \mathrm{C}$ for $2 \mathrm{~h}$ a diffraction maximum at $\sim 9^{\circ} 2 \theta(9.8 \AA)$ is present, which corresponds to the collapsed stevensite layer (see below), and enstatite forms (Fig. 1a). These results are in full accordance with Benhammou et al. (2009). The coexistence of $9.8 \AA$ (kerolite-like) layers and enstatite indicates that the onset of dehydroxylation occurs at lower temperatures. A small amount of kerolite-like layers still persists after heating at $950^{\circ} \mathrm{C}$ for $2 \mathrm{~h}$, and simultaneously enstatite becomes more abundant (data not shown). As expected, chlorite, mica and dolomite also decomposed after heating. Therefore the first recrystallization product of Morocco stevensite after dehydroxylation is enstatite. The Ni-stevensite from Othrys mountain also collapsed at below $500^{\circ} \mathrm{C}$, dehydroxylated at temperatures higher than $750^{\circ} \mathrm{C}$ and yielded enstatite at $800^{\circ} \mathrm{C}$ (Christidis \& Mitsis 2006). Such behaviour is comparable to pure talc, which also recrystallizes to enstatite after dehydroxylation at higher temperature i.e. $900-1000^{\circ} \mathrm{C}$ (Brindley \& Lemaitre, 1987).

Heating of the clay fractions of stevensite up to $300^{\circ} \mathrm{C}$ and subsequent EG solvation did not affect the position of the 001 diffraction maximum. Only a progressive decrease of the diffraction intensity was observed instead (Fig. 2). At higher temperatures the 001 diffraction maximum collapsed to $\sim 9.8 \AA$ and did not re-expand after EG solvation. Moreover, the intensity of the new diffraction maximum increased with increasing heating temperature. The appearance of the new diffraction maximum strongly indicates the formation of a kerolite-like phase. The onset of 
formation of this phase is observed at $\sim 400^{\circ} \mathrm{C}$, and it is fully developed at temperatures higher than $500{ }^{\circ} \mathrm{C}$. The rational order of the higher order basal reflections attests to the lack of intermediate stevensite/kerolite mixed layer phase during progressive heating.
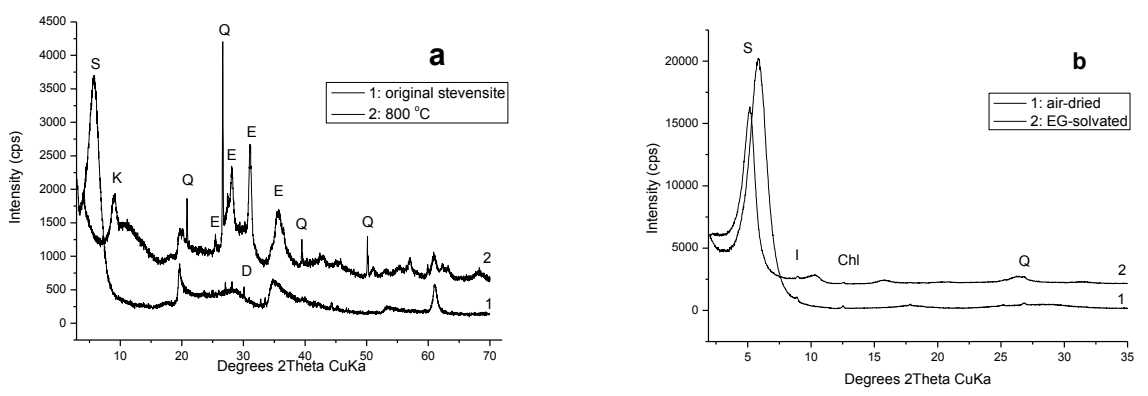

Figure 1 - a) XRD traces of the Jbel Ghassoul stevensite (bulk sample) in raw state and after heating at $800^{\circ} \mathrm{C}$. b) XRD traces of the oriented clay fractions of the original stevensite sample. Key to the symbols: $S=$ stevensite, $K=$ kerolite, $Q=$ quartz, $E=$ enstatite, $D=$ dolomite, $\mathrm{Chl}=$ chlorite, $\mathrm{I}=$ illite. See text for discussion.

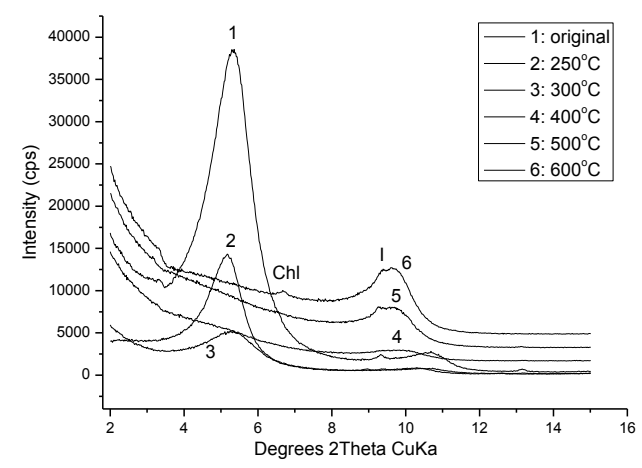

Figure 2- Oriented XRD traces of Jbel Ghassoul stevensite heated at $250-600^{\circ} \mathrm{C}$ and ethylene glycol solvated. $\mathrm{Chl}=$ chlorite, $\mathrm{I}=$ illite.

\subsection{FTIR Spectra}

The FTIR spectra of the original and heated stevensite $\left(500^{\circ} \mathrm{C}\right)$ are shown in Fig. 3. For terms of comparison the FTIR spectrum of a talc is also included. In the $\mathrm{OH}$-streching region all spectra display the characteristic band at $3677 \mathrm{~cm}^{-1}$ attributed to $\mathrm{Mg}_{3} \mathrm{OH}$ (Petit, 2005). The location of the band is identical in all three spectra, but the intensity in stevensite heated at $500^{\circ} \mathrm{C}$ is clearly higher compared the original stevensite and certainly lower than that of talc. In the region of lattice vibrations, the FTIR spectra of the original clay fractions are broader, while the bands of the heated sample seem to be more symmetric. The bands at $451 \mathrm{~cm}^{-1}, 471 \mathrm{~cm}^{-1}$ and $533 \mathrm{~cm}^{-1}$ are attributed to $\mathrm{Si}-\mathrm{O}-\mathrm{Mg}$ vibration, $\mathrm{Mg}-\mathrm{O}$ and/or translational $\mathrm{OH}$-vibration and $\mathrm{Mg}-\mathrm{O}$ vibration respectively. In the $\mathrm{Mg}_{3} \mathrm{OH}$ bending region the stevensite and the heated stevensite display a doublet $\left(668\right.$ and $690 \mathrm{~cm}^{-1}$ ) but the intensity of the two bands is reversed after heating. Talc displays is single band $\left(668 \mathrm{~cm}^{-1}\right)$. In conclusion, although heating caused structural differences in the structure of stevensite, the heated sample has clearly distinct structural features compared to well crystallized talc, being more typical to kerolite (Christidis \& Mitsis, 2006). 


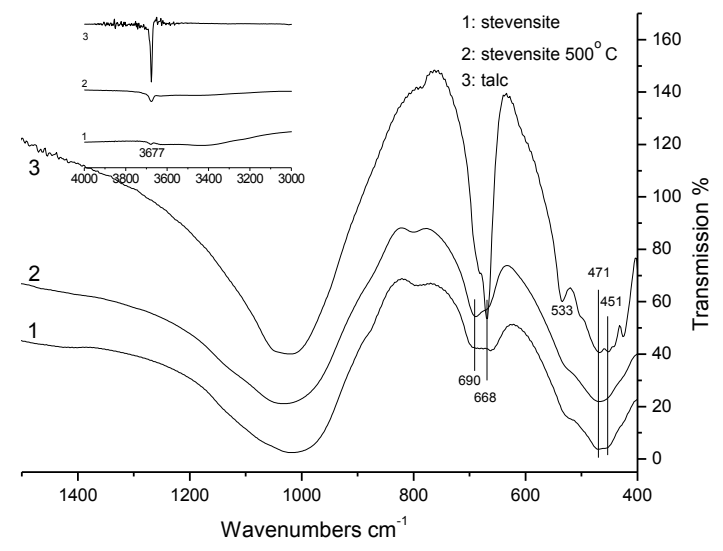

Figure 3 - Mid FTIR spectra of the Jbel Ghassoul stevensite in raw state and after heating at $500^{\circ} \mathrm{C}$. The IR spectrum of talc is shown for comparison. See text for discussion.

\section{Discussion}

This work has clearly shown that stevensite is different than the remaining trioctahedral smectites not only due to the origin of layer charge (octahedral vacancies vs ionic substitution in the structure) but also because although it has comparable dehydroxylation temperature with saponite and hectorite (Paterson and Swaffield, 1987), the swelling properties are lost after heating well below the dehydroxylation temperature. This difference in thermal behaviour has been used recently as part of a new approach to identify the trioctahedral smectites (Christidis and Koutsopoulou, 2013). The loss of swelling is associated with the solid state transformation of stevensite to kerolite-like layers. Kerolite is disordered talc with similar XRD characteristics as smectites, which does not swell in EG vapours (Brindley 1984). It often forms random mixed layer phases with stevensite in nature (Eberl et al., 1982; Dekov et al., 2008). The lack of intermediate mixed layer stevensite/kerolite indicates the presence of homogeneous stevensite domains in the original clay. If minor kerolite domains were present in the original clay, then they should form distinct areas and should not be mixed with stevensite domains (Christidis and Mitsis, 2006). Such a hypothesis explains the XRD traces after EG solvation, which are not compatible with the existence of mixed layer phases. In this scenario, any trace distinct kerolite domains would possibly be masked by the 002 diffraction maximum of stevensite, due to their low abundance.

Heating at $800^{\circ} \mathrm{C}$ shed additional light on the structural characteristics of stevensite. The coexistence of abundant kerolite-like layers and neoformed enstatite crystals is in accordance with the widely accepted influence of kinetics on the transformation of kerolite to enstatite (Brindley \& Lemaitre, 1987). What is not known with certainty is if this kinetic influence on the transformation, is due to existence of energy barriers, or due to structural heterogeneity of the original stevensite. This study has shown that the stevensite layers are relatively homogeneous, due to the apparent lack of kerolite domains. However, the Jbel Ghassoul stevensite contains $1.31 \% \mathrm{Al}_{2} \mathrm{O}_{3}$ (Benhammou et al., 2009), suggesting the presence of saponite layers, although part of this $\mathrm{Al}_{2} \mathrm{O}_{3}$ is due to the presence of traces of chlorite and illite. It is thus suggested that the presence of saponite layers, which also yield enstatite at temperatures higher than $800^{\circ} \mathrm{C}$ (Brindley and Lemaitre, 1987), may also affect the kinetics of transformation of stevensite.

Due to their high dehydroxylation temperatures trioctahedral smectites in general have good potential for application in the foundry industry (iron ore pelletization and foundry sand binders) and as fire retardants (Christidis, 2011). However it is clear that stevensite does not follow this trend, because it converts to a kerolite-like phase at least $400^{\circ} \mathrm{C}$ lower than the dehydroxylation temperature. Therefore, the swelling properties which are of vital importance for foundry applications deteriorate at temperatures lower than the trans-vacant smectites, which 
dehydroxylate at $500-550^{\circ} \mathrm{C}$ (Drits et al. 1998; Guggenheim \& Koster van Groos, 2001). It is well known that trans-vacant smectites are not suitable for foundry applications (Christidis, 2011). This underlines the significance of identification of stevensite layers during assessment of bentonite deposits, in areas where it occurs in close association with saponite, such as the Vicalvaro Basin, Spain (Cuevas et al. 2003). In contrast, due to its fine grain size and swelling properties, coupled with the chemical composition, stevensite is used as a gelling agent, especially after modification with organic compounds, and in the formulation of cordierite ceramics (Benhammou et al. 2009).

\section{Conclusions}

The Jbel Ghassoul stevensite was heated in the temperature range $250-800^{\circ} \mathrm{C}$. Heating above $400^{\circ} \mathrm{C}$ resulted to collapse of the stevensite layers and to formation of non-swelling kerolite-type layers. This transformation occurs well below the dehydroxylation temperature of stevensite. At $800^{\circ} \mathrm{C}$ enstatite forms but the transformation of the kerolite layers is not complete. Identification of stevensite layers is a vital importance during assessment of bentonites containing trioctahedral smectites, especially for high temperature applications such as the foundry industry.

\section{References}

Alberti A. and Brigatti M.F. 1985. Crystal chemical differences in Al-rich smectites as shown by multivariate analysis of variance and discriminant analysis, Clays and Clay Minerals, 33, 546-558

Benhammou A., Tanouti B., Nibou L., Yaacoubi A. and Bonnet J.-P. 2009. Mineralogical and physicochemical investigation of Mg-smectite from Jbel Ghassoul, Morocco. Clays and Clay Minerals, 57, 264-270.

Brigatti M.F. and Poppi L. 1981. A mathematical model to distinguish the members of the dioctahedral smectite series. Clay Minerals, 16, 81-89.

Brindley G.W. 1984. Order-disorder in clay mineral structures, in Brindley G.W., and Brown G. (eds) Crystal Structures of Clay Minerals and their X-ray Identification, 319-370, London, Mineralogical Society, Monograph 5.

Brindley G.W., Bish D.L. and Wan H-M. 1977. The nature of kerolite, its relation to talc and stevensite, Mineralogical Magazine, 41, 443-452.

Brindley G. and Lemaitxe, J. 1987. Thermal, oxidation and reduction reactions of clay minerals. In Newman, A.C.D. and Brown, G. (eds), Chemistry of Clays and Clay Minerals, 319-370, London, Mineralogical Society.

Christidis G.E. 2006. Genesis and compositional heterogeneity of smectites, Part III, Alteration of basic pyroclastic rocks, A case study from the Troodos Ophiolite Complex, Cyprus, American Mineralogist, 91, 685-701

Christidis G.E. 2011. Industrial clays, in Christidis, G.E. (ed) Advances in the Characterization of Industrial Minerals, 341-414, London, EMU Notes in Mineralogy, vol. 9, Mineralogical Society, $485 \mathrm{pp}$.

Christidis G. and Dunham A.C. 1993. Compositional variations in smectites derived from intermediate volcanic rocks. A case study from Milos Island, Greece, Clay Minerals, 28, $255-273$

Christidis G. and Dunham A.C. 1997. Compositional variations in smectites, Part II: Alteration of acidic precursors. A case study from Milos Island, Greece. Clay Minerals, 32, 255-273.

Christidis G.E. and Eberl D.D. 2003. Determination of layer charge of smectites, Clays and Clay Minerals, 51, 644-655.

Christidis G.E. and Mitsis I. 2006. A new Ni-rich stevensite from the ophiolite complex of Othrys, central Greece, Clays and Clay Minerals, 54, 653-666.

Christidis G.E. and Koutsopoulou E. 2013. A novel approach to identify trioctahedral smectites by $\mathrm{X}$-ray Diffraction. International Conference, "Minerals for Life: Overcoming Resource Constraints" 17-20 June, 2013, Edinburgh, UK, Book of Abstracts. 
Cuevas J., de la Villa, R.V., Ramirez S, Petit S., Meunier A. and Leguey S. 2003. Chemistry of $\mathrm{Mg}$ smectites in lacustrine sediments from the Vicalvaro sepiolite deposit, Madrid, Neogene Basin (Spain), Clays and Clay Minerals, 51, 457-472

Decarreau A., Colin F., Herbillon A., Manceau A., Nahon D., Paquet H., Trauth-Badeaud D. and Trescases, J.J., 1987. Domain segregation in Ni-Fe-Mg-smectites, Clays and Clay Minerals, 35, 1-10.

Dekov V.M., Cuadros J., Shanks, W.C. and Koski R.A. 2008 Deposition of talc-kerolite-smectite smectite at seafloor hydrothermal vent fields: Evidence from mineralogical, geochemical and oxygen isotope studies, Chemical Geology, 247, 171-194.

Drits V.A., Lindgreen H., Salyn A.L., Ylagan R. and McCarty D.K., 1998. Semi quantitative detrmination of trans-vacant and cis-vacant 2:1 layers in illites and illite-smectites by thermal analysis and X-ray diffraction. American Mineralogist, 83, 1188-1198.

Eberl D.D., Jones B.F. and Khoury, H.N., 1982. Mixed-layer kerolite/stevensite form the Amargosa Desert, Nevada. Clays and Clay Minerals, 30, 321-326.

Goodman B.A., Nadeau P.H., and Chadwick, J. 1988. Evidence for the multiphase nature of bentonites from Mossbauer and EPR spectroscopy, Clay Minerals, 23, 147-159.

Greene-Kelly R. 1953. Irreversible dehydration in montmorillonite, Part II, Clay Minerals Bulletin, 2, 52-56.

Grim R.E. and Kulbicki G. 1961. Montmorillonite: High temperature reactions and classification. American Mineralogist, 46, 1329-1369.

Guggenheim S. and Koster van Groos A.F. 2001. Baseline studies of the Clay Minerals Society Source YS: Thermal Analysis, Clays and Clay Minerals, 49, 433-443.

Güven N. 1988. Smectite, In Bailey, S.W., ed., Hydrous Phyllosilicates 497-559, Reviews in mineralogy, 19, Mineralogical Society of America.

Iwazaki T., and Watanabe T. 1988. Distribution of $\mathrm{Ca}$ and $\mathrm{Na}$ ions in dioctahedral smectites and interstratified dioctahedral mica/smectites. Clays and Clay Minerals. 36, 73-82.

Lagaly G. and Weiss A. 1975. The layer charge of smectitic layer silicates, Proceedings International Clay Conference Mexico, 157-172.

Lagaly G., 1994. Layer charge determination by alkylammonium ions, in Mermut, A.R., ed., Layer charge characteristics of 2:1 silicate clay minerals, 2-46, Boulder Colorado, CMS Workshop lectures, 6. The Clay Minerals Society.

Lim C.H. and Jackson M.L. 1986. Expandable phyllosilicate reactions with lithium on heating, Clays and Clay Minerals, 34, 346-352.

Moore D.M. and Reynolds, R.C., Jr., 1997. X-ray diffraction and the identification and analysis of clay minerals. $2^{\text {nd }}$ edition, Oxford University Press, New York.

Newman A.C.D. and Brown, G., 1987. The chemical constitution of clays. In Newman, A.C.D., ed., Chemistry of Clays and Clay Minerals, 1-128, London, Mineralogical Society.

Paterson E. and Swaffield R. 1987. Thermal Analysis. In Wilson M.J., ed. A Handbook of Determinative Methods in Clay Mineralogy, 99-132, Glasgow, UK, Blackie \& Son Limited.

Petit S. 2005. Crystal-chemistry of talcs: A NIR and MIR spectroscopic approach. In J.T. Kloprogge. (ed), The Application of Vibrational Spectroscopy to Clay Minerals and Layered Double Hydroxides, 41-64, Aurora CO 80046-0130, The Clay Minerals Society, $285 \mathrm{pp}$.

Russell J.D. 1987. Infrared Methods. In: M.J. Wilson (ed.) A handbook of determinative methods in clay mineralogy, 133-173, Glasgow \& London, Blackie.

Schultz L.G. 1969. Lithium and potassium adsorption, dehydroxylation temperature and structural water content of aluminous smectites, Clays and Clay Minerals, 17, 115-149.

Shimoda S. 1971. Mineralogical studies of a species of stevensite from the Obori Mine, Yamagata prefecture, Japan, Clay Minerals, 9, 185-192.

Talibudeen O. and Goulding, K.W.T. 1983. Charge heterogeneity in smectites. Clays and Clay Minerals, 31, 37-42.

Wolters F., Lagaly G., Kahr G., Nüesch R. and Emmerich, K. 2009. A comprehensive characterization of dioctahedral smectites, Clays and Clay Minerals, 57, 115-133. 